\title{
Metal dynamics in a tropical watershed: The São Francisco river and its compartments
}

\author{
Isabela Claret Torres ${ }^{1}$ \\ Adolf Heinrich Horn ${ }^{2^{*}}$ \\ Rodrigo Silva Lemos ${ }^{1}$ \\ ${ }^{1}$ Department of Geography \\ Geoscience Institute \\ Federal University of Minas Gerais \\ Av. Antonio Carlos 6627 \\ Campus Pampulha \\ Belo Horizonte MG Brasil \\ CEP 31270-901 \\ ${ }^{2}$ Department of Geology \\ Geoscience Institute \\ Federal University of Minas Gerais \\ Av. Antonio Carlos 6627 \\ Campus Pampulha \\ Belo Horizonte MG Brasil \\ CEP 31270-901 \\ Corresponding author: \\ hahorn@gmail.com \\ Phone: +55 31988739910
}

\begin{abstract}
Water ecosystems are one of the most threaten environments due to anthropogenic pressures, among them the contamination of metals that are toxic to every life form. The main objective of this paper was to investigate the role of each compartment of a river system in metal dynamics using metal sediment concentration. To accomplish the objective sediments from several sites in a tropical river drainage basin were sampled comprising different types of compartments: : the river channel, the dry and wet inundation area and marginal lagoons, as well a pristine site with no anthropogenic impact. A Principal Component Analysis and the calculation of the Enrichment Factor and Index of Geoacummulation were conducted. The results showed that was no great difference of Index of Geoaccumulation among the different compartments. However, the Enrichment Factor was higher in wet inundation areas followed by dry soils from inundation areas and dry lagoons. Principal Component Analysis selected the metals $\mathrm{Fe}, \mathrm{Cu}$ and $\mathrm{Mg}$ in axis 1, while axis 2 selected $\mathrm{Mg}$ and $\mathrm{Ba}$. Although there was not a clear separation in the results of the multivariate analysis among sites across a transect, the analysis separated the compartments in relation to the concentration of metals. The results showed that each compartment had its own dynamics in relation to accumulation of metals present in the river basin. The study shows the importance of studying different types of habitats of a drainage basin to stablish best management practices.
\end{abstract}

Keywords: metals, river, compartments, sediment, São Francisco river

\section{RESUMO}

Ecossistemas aquáticos são um dos mais ameaçados hoje em dia devido a pressões antrópicas, sendo entre elas uma das mais importantes a contaminação por metais que são tóxicos a todas formas de vida. O principal objetivo desse trabalho foi o de investigar o papel de cada compartimento de um sistema fluvial na dinâmica de metais usando a concentração destes no sedimento. Para isso sedimentos de diferentes pontos em uma bacia de drenagem tropical foram amostrados abrangendo diferentes tipos de compartimentos: o canal do rio, áreas de inundações húmidas e secas, lagoas marginais, e um ponto sem pressão antrópica. Uma Análise de Componente Principal (PCA) e o cálculo do Fator de Enriquecimento (FE) e o Índice de Geoacumulação (Igeo) foram realizados. Os resultados demonstraram que não houve grandes diferenças de Igeo entre os pontos amostrados. Entretanto, o EF foi maior nas áreas de inundações húmidas seguida pelas secas e lagoas secas. O PCA selecionou os metais $\mathrm{Fe}, \mathrm{Cu}$, e $\mathrm{Mg}$ no eixo 1, enquanto que o eixo 2 selecionou $\mathrm{Mg}$ e $\mathrm{Ba}$. Apesar de não ter ocorrido uma grande separação dos pontos dos amostrados através de um transecto, a análise separou os compartimentos em relação à concentração de metais. Os resultados demonstraram que cada compartimento tem sua própria dinâmica em relação ao acúmulo de metais presentes na bacia de drenagem. O estudo mostrou a importância de se estudar diferentes tipos de habitats de uma bacia de drenagem para o estabelecimento de práticas de manejo.

Palavras-chave: metais, rio, compartimentos, sedimentos, rio São Francisco 


\section{INTRODUCTION}

World population growth and the intensification of different forms of land use and occupation have increased environmental pressure on natural habitats. River systems, in this context, are impacted by changes in water quality, as well as a significant reduction in the amount of water available for a wide range of human uses and ecosystem functioning.

In relation to water quality, there has been great concern regarding the contamination of rivers by metals (Islam et al. 2015). The main sources of metals for the environment are related to wastewater from industrial and mining activities, atmospheric input, soil erosion and surface runoff from agriculture practices (Carman et al. 2007, Pizarro et al. 2010, Díaz-Alba et al. 2011, Jiao et al. 2015). The presence of metals in water is of great concern due to their toxicity, persistence and cumulative nature (Díaz-Alba et al. 2011, Nemati et al. 2011). In most cases, in natural environments, without anthropogenic influence, the concentration of metals is low and derived mainly from soil particles and rock weathering (Reza \& Singh 2010). The metals that occur in minerals usually have low mobility, as they are linked to their crystalline structure. On the other side, those of anthropogenic origin have weak fixation to the substrate, allowing them to have high mobility (Heltai et al. 2005, Passos et al. 2010, Ghrefat et al. 2012, Saleem et al. 2015).

In countries in economic and social development such as Brazil, the discharge of industrial and domestic effluents in rivers is a recurrent practice that generates strong impacts on river systems and diminishes the possibilities of using water resources. Another important source of pollution is the diffuse pollution generated by runoff in urban areas and in regions of agricultural activities. Diffuse pollution refers to those materials that are carried by surface runoff from rainwater, some of these materials are metals, oils, phosphates and nitrates, residues of burning, organic compounds and other residues of the most varied sources. The treatment for diffuse pollution is very complex and difficult to apprehend, since it is necessary to define the sources of pollution and their composition, as well as the quantity of materials carried by the rainwater. Diffuse material continuously accumulates on surfaces and is easily carried in the first rainfalls. Potential for pollutant accumulation and rainwater collection are variables that depend essentially on soil type, prevailing anthropogenic uses and site topography. (Dotto \& Paiva, 2006).

The presence of metals in watercourses is an important health issue due to the possibility of humans and animals contamination (Weber et al. 2013). Metals can be toxic, have long persistence in water and show bioaccumulation and biomagnification in the food chain. Metals can accumulate in fish tissue, thus posing a threat to humans that use this type of protein in their diet. (Yousafzai et al. 2010, Harguinteguy et al. 2014)

Once in the aquatic environment, metals can be in dissolved or particulate forms (Tuna et al. 2007). Over time, metals in the particulate fraction can settle and become integral part of sediments. Metals that are present in sediments can be released to the water column due to changes of $\mathrm{pH}$, redox potential and resuspension (Sundelin \& Eriksson 2001, Roberts 2012, Hill et al. 2013). Consequently, metals are constantly being deposited in the sediments and released to the water column as dissolved and particulate fractions.

The fluvial system can be divided in different compartments, each one showing varied dynamics and resulting in different features and environments. The river channel, the inundation area (that can be wet or dry during some periods of the year) and marginal lagoons (wet or dry) stand out as important environments for the maintenance of the hydrosedimentological dynamics of the river.

In most cases, there is no previous treatment on these altered waters, nor the ability of monitoring by the environmental agencies, which generates recurrent contexts of water pollution. Due to the geographical situation, rivers are often the only source of drinking water for the local population. Increasing wastewater inflow from different human activities is 
decreasing the water quality of these natural water bodies, and its potential use. In recent years, due to the contexts of scarcity, but mainly also to the poor water management capacity, some Brazilian states have experienced problems related to the amount of water available for human supply. With the reduction of water quantity, its quality has become one major problem for the management of water resources and the compatibilization of multiple uses, as proposed by the national water resources policy.

The São Francisco river drains an extensive area of the Brazilian territory, being its firsts springs located in the state of minas Gerais (southeast region of Brazil) and the river mouth in the border of the states of Sergipe and Alagoas (northeastern region). It is one of the most important rivers for the country and its basin is responsible for supplying water for a population of approximately 14.2 million ( $7.5 \%$ of the Brazilian population) in a territory with different economic activities. This river is of great importance because it drains vast arid lands in Brazil, being the only source of water for the local population.

The water resources of the main channel and its tributaries are used for different purposes, with emphasis on human

\section{MATERIAL AND METHODS}

\subsection{STUDY AREA}

The São Francisco River watershed covers an area of eight federal units in Brazil: Minas Gerais, Bahia, Goiás, Pernambuco, Alagoas, Sergipe and the Distrito Federal (Brasília). Its drainage basin represents $8 \%$ of Brazilian territory with a drainage area of $634.000 \mathrm{~km}^{2}$. The São Francisco River has an extension of over $2.700 \mathrm{~km}$, with its springs located in Minas Gerais State (Canastra National Park) and the River mouth situated in the State of Alagoas. The River drains five states and 521 municipalities. It covers an area with middle to high hydric deficit and in many regions is the primary source of water for the local population. This extensive drainage basin is divided into four distinct zones (Patrus et al., 2001): A) consumption, energy production, irrigation and intense agricultural activities, disposal of wastewater from domestic and industrial activities. Therefore, the quality of its waters is of great concern, since the decrease in quality can have strong social and economic impacts. Several studies have already shown that metal contamination of its waters and sediments is an important issue in the drainage basin of São Francisco river (Horn \& Baggio 2011; Horn et al. 2012; Horn et al. 2014; Palmares et al. 2016). However, these studies were conducted mainly in the river channel, not addressing the different compartments of the river system.

The main objective of this study was to verify if the different compartments of the São Francisco river have different metal dynamics. The specific objectives were:

1) Determine the concentration of metals in the different compartments;

2) Verify if there is difference in metal concentration in the different compartments and which metals accumulate in each compartment;

3) Determine the Enrichment Factor and Index of Geoaccumulation for each compartment;

4) Determine which of the compartments are the main retention site of metals.

the Upper São Francisco (from its spring till the city of Pirapora/Minas Gerais), B) The Middle São Francisco (Pirapora till the Sobradinho Lake in Bahia State), C) Sub medium São Francisco (Remanso till Paulo Afonso, both in Bahia State) and D) Low São Francisco (Paulo Afonso till the Atlantic Ocean in Alagoas State).

The study area belongs to the upper to middle São Francisco River basin, covering an area from its springs until Pirapora city, all located in Minas Gerais State (Fig. 1). The climate of the region is classified (Köppen) as Aw, a typical raining tropical climate, with hot and humid summer months, and "dry" winter. The raining season with mean precipitation of $12 \mathrm{~mm}$ occurs from November until March. 


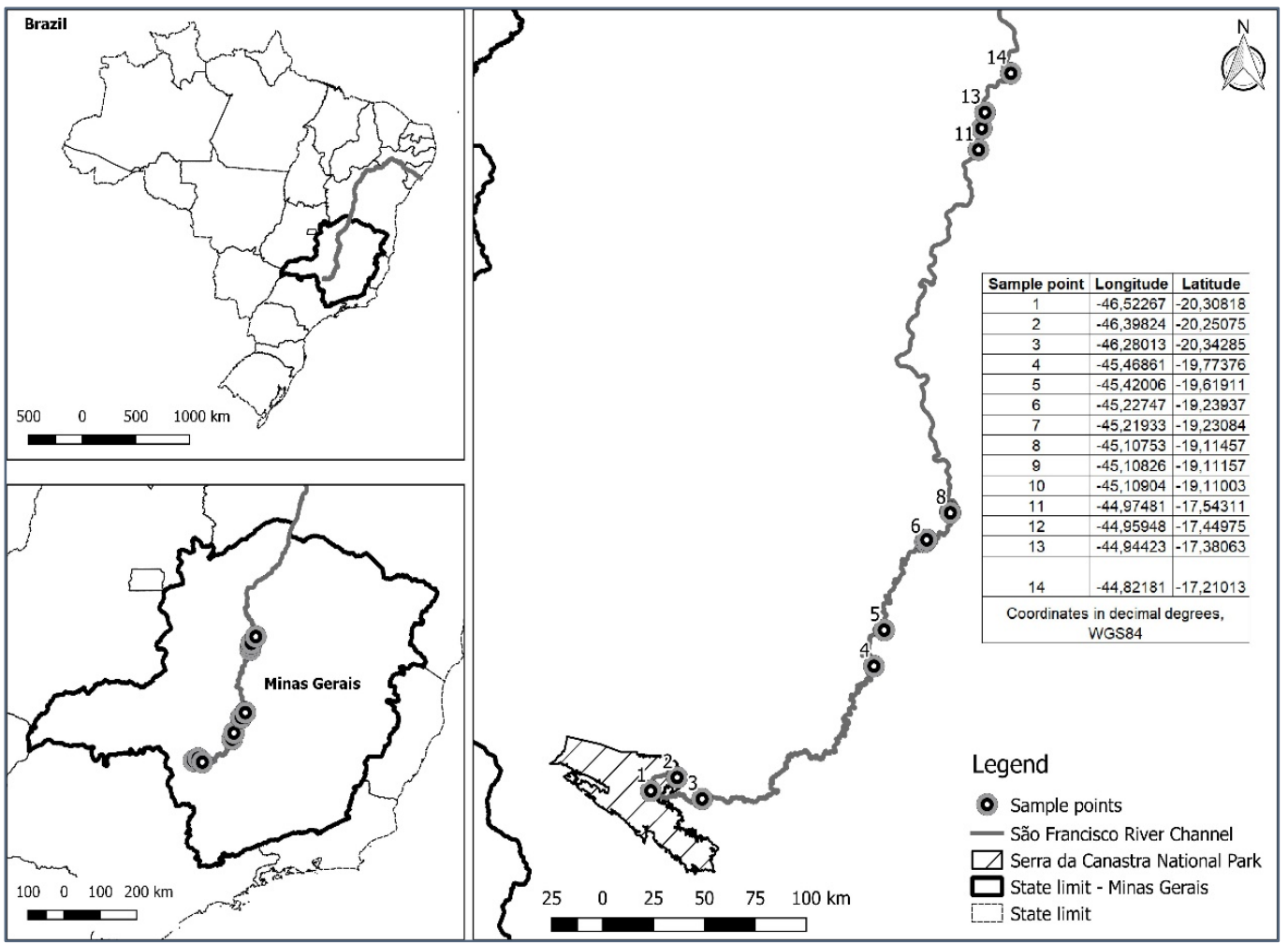

Figure 1

Map of São Francisco river and sampled sites.

Different compartments of the river were sampled: Sediment from a pristine area right after de Canastra National Park; sediments in the margin of the river; sediments in wet inundation areas; sediments from marginal lagoons; soils from dry inundation area or dry marginal lagoons (Table 1). The main anthropic pressures are related to industrial and agricultural activities and house holding. Among the industrial activities, there are zinc processing, metallurgy (iron and silicon) and textile industries. The agricultural activities are diverse and range from small ranches until the production of corn, soy, cotton, coffee, eucalyptus, Pinus

\subsection{ANALYTICAL METHODS}

Sediments were oven dried at $30{ }^{\circ} \mathrm{C}$ for 24 horas. Samples were grounded and passed through a mesh of $0.063 \mathrm{~mm}$, which is the fraction where metals can be found (Salomons and Forstner, 1984). The particle size separation was carried out in accordance with the NBR 7181 (ABTN 1984). The fine sediment $(0.063 \mathrm{~mm})$ was subjected to acid digestion in microwave sp. and livestock and fish farms. There is also the disposal of domestic effluents without previous treatment in its waters.

The sediments were sampled in February 2017 and April 2017. Fourteen sites were sampled since right after its springs till marginal lagoons in Pirapora City. Depending on the site different samples were taken, in different areas or depths (Table 1). The samples were retrieved with a nonmetallic shovel, placed in plastic bags, kept on ice till its transport to the laboratory. In the laboratory, the samples were kept under $4^{\circ} \mathrm{C}$ till the beginning of the analyses.

MARS-CEM in accordance to the method SW-846-3051 - US EPA (US EPA 1998). About $0.50 \mathrm{~g}$ of fine fraction of the sediment was digested with $10 \mathrm{ml}$ of concentrated nitric acid (HNO3) for 10 minutes (ramp time) and temperature stabilization at $180^{\circ} \mathrm{C}$ and pressure (350 psi) for 4'30"(hold time). Samples were then filtered in cellulose filter $(0.45 \mu \mathrm{m})$ 
and analyzed in an ICP-OES (Spectroflame from Spectro Analytical Instruments). The concentration of $\mathrm{Mg}, \mathrm{Al}, \mathrm{Ca}, \mathrm{Cr}, \mathrm{Fe}, \mathrm{Co}$,
$\mathrm{Cu}, \mathrm{Cd}, \mathrm{Ti}, \mathrm{Mn}, \mathrm{Ni}, \mathrm{Zn}, \mathrm{Ba}$ and $\mathrm{Pb}$ were determined. The results are reported in $\mathrm{mg} \cdot \mathrm{kg}^{-1}$ on a dry weight basis.

Table 1 - Description of sampled sites Where A: Sediments from marginal lagoons, B: Soils from inundation area or dry lagoons, C: Sediment from wet inundation areas, D: Sediment from pristine area of the river and E: Sediment from impacted areas of the river.

\begin{tabular}{|c|c|c|c|c|c|c|}
\hline ID & $\begin{array}{c}\text { Type of } \\
\text { Sampled } \\
\text { Site }\end{array}$ & Site & Place of sampling & $\begin{array}{c}\text { Sampling } \\
\text { depth }\end{array}$ & $\begin{array}{l}\text { Type of } \\
\text { Sample }\end{array}$ & Coordinates \\
\hline 1 & $\mathrm{D}$ & Pristine River & Margin of the river & $0-5 \mathrm{~cm}$ & Sediment & $--46,5227 /-20,3082$ \\
\hline 2 & $\mathrm{E}$ & Impacted River & Margin of the river & $0-5 \mathrm{~cm}$ & Sediment & \multirow{2}{*}{$-46,3982 /-20,2508$} \\
\hline $2-1$ & $\mathrm{E}$ & Impacted River & Margin of the river & $5-10 \mathrm{~cm}$ & Sediment & \\
\hline 3 & $\mathrm{C}$ & Inundation Area & Wet & $0-5 \mathrm{~cm}$ & Sediment & $-46,2801 /-20,3429$ \\
\hline 4 & $\mathrm{E}$ & Impacted River & Margin of the river & $0-5 \mathrm{~cm}$ & Sediment & \multirow{2}{*}{$-45,4686 /-19,7738$} \\
\hline $4-1$ & $\mathrm{E}$ & Impacted River & Margin of the river & $5-10 \mathrm{~cm}$ & Sediment & \\
\hline 5 & A & Gentil & $1 \mathrm{~m}$ inside the lagoon & $0-5 \mathrm{~cm}$ & Sediment & \multirow{2}{*}{$-45,4201 /-19,6191$} \\
\hline $5-1$ & A & Gentil & $1 \mathrm{~m}$ inside the lagoon & $5-10 \mathrm{~cm}$ & Sediment & \\
\hline 6 & $\mathrm{~B}$ & Inundation Area & Dry & $0-5$ & Soil & $-45,2275 /-19,2394$ \\
\hline $6-1$ & $\mathrm{~B}$ & Inundation Area & Dry & $0-10 \mathrm{~cm}$ & Soil & $-45,2193 /-19,2308$ \\
\hline 7 & $\mathrm{C}$ & Inundation Area & Wet & $0-5 \mathrm{~cm}$ & Sediment & $-45,2193 /-19,2308$ \\
\hline 8 & $\mathrm{~B}$ & Riacho Farm & Dried Lagoon 1 & $0-5 \mathrm{~cm}$ & Soil & \multirow{2}{*}{$-45,1075 /-17,5431$} \\
\hline $8-1$ & $\mathrm{~B}$ & Riacho Farm & Dried Lagoon 1 & $5-10 \mathrm{~cm}$ & Soil & \\
\hline 9 & $\mathrm{~B}$ & Riacho Farm & Dried Lagoon 2 & $0-5 \mathrm{~cm}$ & Soil & \multirow{2}{*}{$-45,1083 /-19,1116$} \\
\hline $9-1$ & $\mathrm{~B}$ & Riacho Farm & Dried Lagoon 2 & $5-10 \mathrm{~cm}$ & Soil & \\
\hline 10 & $\mathrm{~B}$ & Riacho Farm & Dried Lagoon 3 & $0-5 \mathrm{~cm}$ & Soil & \multirow{2}{*}{$-45,1090 /-19,1100$} \\
\hline $10-1$ & $\mathrm{~B}$ & Riacho Farm & Dried Lagoon 3 & $5-10 \mathrm{~cm}$ & Soil & \\
\hline $11-1$ & A & Guim Lagoon & Inundation area & $0-5 \mathrm{~cm}$ & Sediment & \multirow{4}{*}{$-44,9748 /-17,5431$} \\
\hline $11-2$ & A & Guim Lagoon & $1 \mathrm{~m}$ inside the lagoon & $0-5 \mathrm{~cm}$ & Sediment & \\
\hline $11-3$ & A & Guim Lagoon & $5 \mathrm{~m}$ inside the laggon & $0-5 \mathrm{~cm}$ & Sediment & \\
\hline $11-4$ & A & Guim Lagoon & Middle of the lagoon & $0-5 \mathrm{~cm}$ & Sediment & \\
\hline $12-1$ & $\mathrm{~A}$ & Atoleiro Lagoon & Inundation area & $0-5 \mathrm{~cm}$ & Sediment & \multirow{4}{*}{$-44,9595 /-17,4497$} \\
\hline $12-2$ & A & Atoleiro Lagoon & $1 \mathrm{~m}$ inside the lagoon & $0-5 \mathrm{~cm}$ & Sediment & \\
\hline $12-3$ & A & Atoleiro Lagoon & $5 \mathrm{~m}$ inside the laggon & $0-5 \mathrm{~cm}$ & Sediment & \\
\hline $12-4$ & A & Atoleiro Lagoon & Middle of the lagoon & $0-5 \mathrm{~cm}$ & Sediment & \\
\hline $13-1$ & A & Pontal Lagoon & Inundation area & $0-5 \mathrm{~cm}$ & Sediment & \multirow{4}{*}{$-44,9442 /-17,3806$} \\
\hline $13-2$ & A & Pontal Lagoon & $1 \mathrm{~m}$ inside the lagoon & $0-5 \mathrm{~cm}$ & Sediment & \\
\hline $13-3$ & A & Pontal Lagoon & $5 \mathrm{~m}$ inside the laggon & $0-5 \mathrm{~cm}$ & Sediment & \\
\hline $13-4$ & A & Pontal Lagoon & Middle of the lagoon & $0-5 \mathrm{~cm}$ & Sediment & \\
\hline $14-1$ & A & Formoso Lagoon & Inundation area & $0-5 \mathrm{~cm}$ & Sediment & \multirow{4}{*}{$-44,8218 /-17,2101$} \\
\hline $14-2$ & A & Formoso Lagoon & $1 \mathrm{~m}$ inside the lagoon & $0-5 \mathrm{~cm}$ & Sediment & \\
\hline $14-3$ & A & Formoso Lagoon & $5 \mathrm{~m}$ inside the laggon & $0-5 \mathrm{~cm}$ & Sediment & \\
\hline $14-4$ & A & Formoso Lagoon & Middle of the lagoon & $0-5 \mathrm{~cm}$ & Sediment & \\
\hline
\end{tabular}

* Geographic coordinates were measured in Datum WGS1984.

\subsection{DATA ANALYSIS}

The results were used in a Principal Component Analysis (PCA). The PCA consists of a multivariate analysis that is used to predict and describe structural patterns, using a large data set. This analysis describes the structure of a database quantifying the degree of association between the variables and objects (samples), thus defining biological communities and areas or periods of the same ecological characteristics (Pla 1986,
Valentin 1995). The PCA technique is of assortment in which the variables are positioned on two or more axes so that their positions provide information on their similarities and differences. This technique is used to simplify, condense and represent synthetically vast data sets (Jollife 1986, Pla 1986, Valentin 1995). Statistical analyzes were performed using Statistica software version 7.1 for Windows (Stat Soft Inc. 2006). 
The Enrichment Factor (EF) was calculated by the following formula (Loska \& Wiechula 2003):

$$
E F(\%)=\frac{C-C \min }{(C \max -C \min )} * 100
$$

Where $\mathrm{C}$ is the mean metal concentration, $\mathrm{C} \max$ and $\mathrm{C} \min$ are the maximum and minimum concentration respectively. As this calculation deals with mean, maximum and minimum values the EF was calculated grouping the data for each different compartment. As the intention was to verify the enrichment rela-

\section{RESULTS AND DISCUSSION}

The pristine site had the lowest concentration for almost all measured metals. Only for $\mathrm{Ca}, \mathrm{Cu}$ and $\mathrm{Ti}$ the concentrations were not the lowest in the pristine site. The minimum and maximum concentration (in $\mathrm{mg} \cdot \mathrm{kg}^{-1}$ ) in all sample sites were as followed: $\mathrm{Mg}$ : 85-2176, Al: 1605-53823, Ca: 243-1571, Cr: < 0.001-37, Fe: 742-5342, Co: <0,0068-10.2, Cu: 10.840, Cd: not detected in any sample, Ti: 15.6-168, Mn: 10.2-778, Ni: 8.8-18.4, Ba: 19.6-273 and $\mathrm{Pb}$ : <0,0349-68 (Table 2). Several analyses (i.e. plots, PCA) were done trying to stablish a relationship between the distance from the pristine site and the other sites and the increased concentration of metals (Data not shown). No clear relationship was stablished, as the concentration of metals were variable among the distance from the pristine site. This indicates that there is not an increase in metal concentration with distance from the main spring of São Francisco river. In a first thought this relation was supposed to be clear. As much as the river flows from pristine sites till areas of high human activity its is fair to suppose that metals concentration will increase with the distance as more effluent from human activities reach the river. As more contaminated effluents enters the river it is expected that they will settle and accumulate in the sediments. That was not the case. There was not a clear pattern of increasing metal concentration with distance from the pristine site (data not ted to the pristine site the values observed for this site were used as the minimum concentration.

The Index of Geoaccumulation (Igeo) was calculate by the following formula (Loska \& Wiechula 2003):

$$
\text { Igeo }=\frac{\log 2(C n)}{1.5 * B n}
$$

Where $C n$ is the concentration of the metals in the sample, $B n$ is the background concentration. The metal concentration measured in the pristine site were used as a background concentration.

shown), although the PCA showed a separation among sites which will be presented latter. This indicates that other issues are more important in determining metal concentration in the sediments of the different compartments. Ciazela et al. (2018) states that metal concentration in the bottom sediments of freshwater ecosystems are controlled by a variety of human and environmental factors. Among them we can cite: 1) grain size fractionation, 2) chemical fractionation, 3) vicinity of urban areas, and 4) geogenic input (Ciazela et al. 2018).

The Enrichment Factor (EF) was very high for all types of compartment (Table 3). Toxic elements like $\mathrm{Pb}, \mathrm{Cu}$ and $\mathrm{Cr}$ had values that reached $88,6 \%, 99,6 \%$ and $83,8 \%$ respectively (Table 3 ). The Compartment $\mathrm{C}$ which is the sediments from wet inundation areas had the highest values for most of metals, followed by Compartment $\mathrm{B}$ which are dry soils from inundation area and dry lagoons. On the other side, sediments from marginal lagoons had the lowest values for EF. Although marginal lagoons of the São Francisco hydrographic basin have been shown to accumulate metals in its sediments (Trindade 2016), it seems that the inundation areas are the sites where accumulation is more prominent. This result shows the importance of inundation areas to absorb impacts caused by pollution of rivers. The main mechanism that leads the inundation area (dry or wet) to have highest EF than the other compartments 


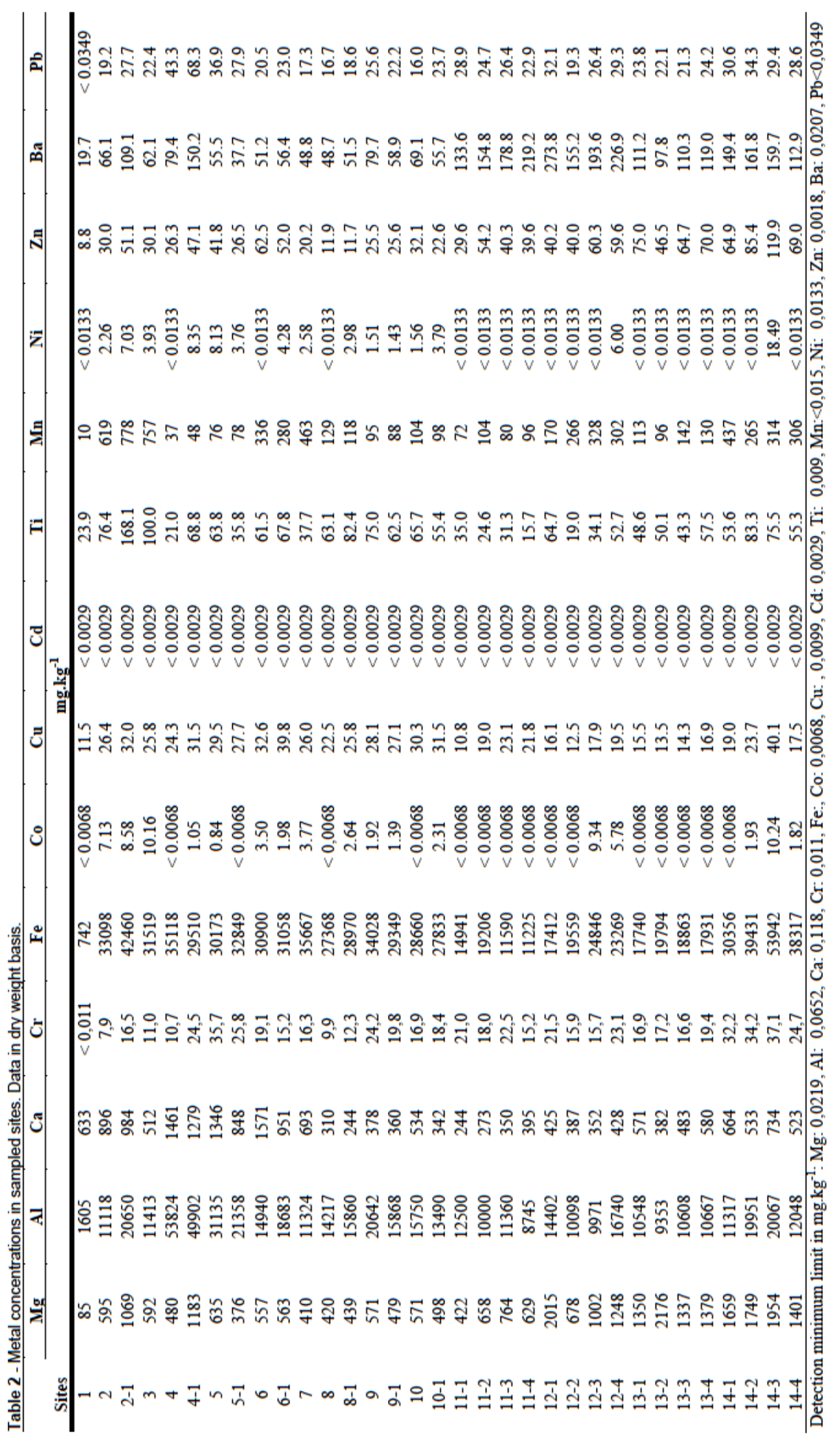


is not clear. It could not be found in the scientific literature any possible explanation for this fact. However, one explanation might be as inundation areas are more prone to have the influence of both the river and surface run off, some of metals that come with these allochthonous water might deposit in these areas before they reach the river. In addition, when these areas are wet the water usually is stagnant; there is no movement, which allows the metals particles to settle. Somehow when these areas get dry the metals can bind to soil particles and become retained in these sites.

Even though compartments B and C had the highest values, all other compartments show high EF. Its important to point out that background values for the calculation of EF were based on metal concentration founded in the pristine site. This indicates that the São Francisco river basin is receiving a considered load of metals that are being retained in its sediments and soils. As pointed out in this important hydrographic basin there is both industrial and agricultural activities which generate effluents with possible metal contamination. Among them we can cite zinc processing industry, metallurgy (iron and silicon) and textile industries. Both fertilizers and agrochemicals are known to contain metals, and in this area there is a large production of corn, soy, cotton, coffee, eucalyptus, Pinus sp. Other studies have already shown that sediment metal contamination is an important issue in São Francisco hydrographic basin (Horn \& Bagio 2011; Horn et al. 2012, Trindade 2016). Our results show that sites with anthropogenic pressures are showing a very high metal enrichment when compared with sites with no impacts in this hydrographic basin.

The Index of Geoaccumulation was also high in the sampled sites for most metals. Values varied from 6,9 till 20,6. But there was no significant difference among sites (Table 4). However, the results show that there is high contamination of all sediments by all metals analyzed when comparing with data of other aquatic systems throughout the world (Tamin et al. 2016, Dai et al. 2017).

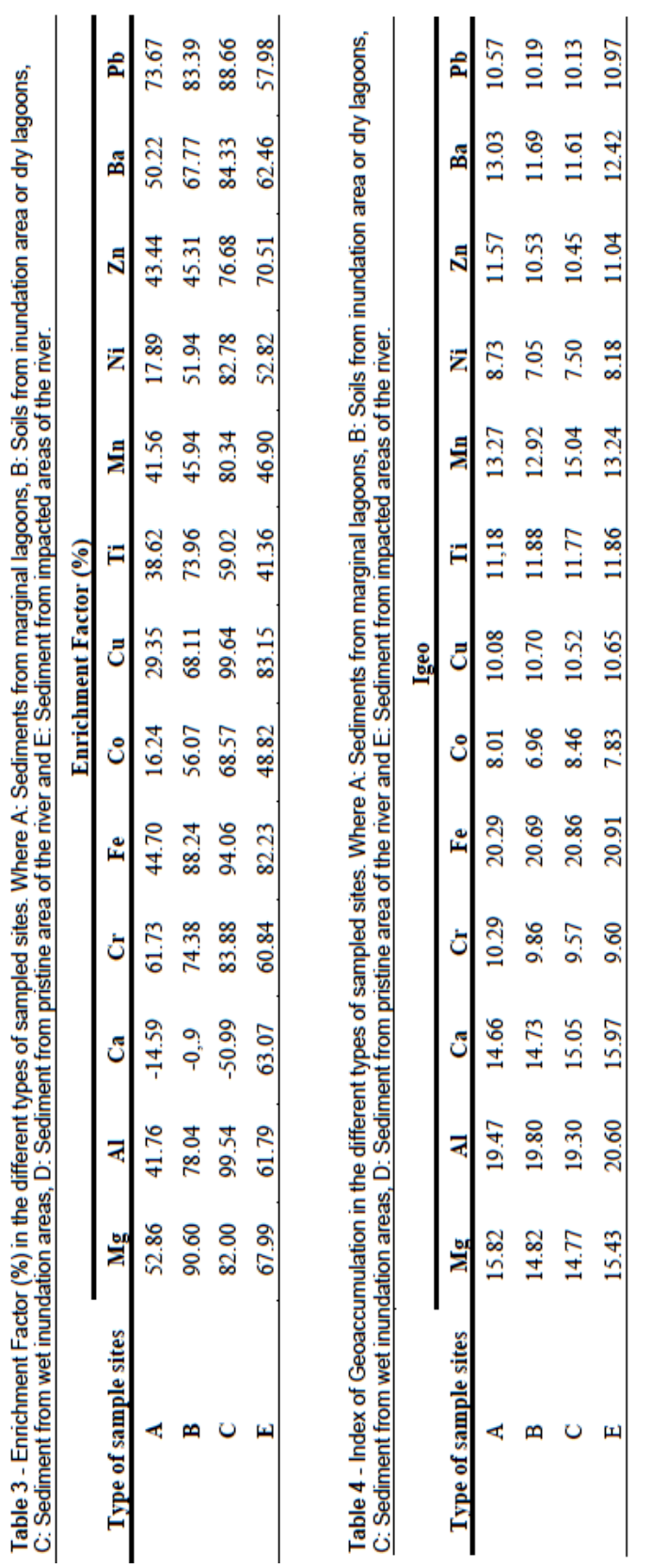


The Principal Component Analysis (PCA) showed interesting results (Fig. 2, Table 5). The PCA explained $72,2 \%$ of the data variability. The PC1 with $45,1 \%$ of the variability selected $\mathrm{Fe}, \mathrm{Cu}$ and $\mathrm{Mg}$, while PC2 with 27,1\% selected Mg and Ba (Table 5). When PCA selects the elements it means that the occurrence and concentration of these are the most influential in the percentage data variability. The metals $\mathrm{Ba}$, $\mathrm{Mg}, \mathrm{Zn}, \mathrm{Cr}$ and $\mathrm{Pb}$ seem to occur in the same pattern in the selected sites. While $\mathrm{Ni}$, $\mathrm{Fe}, \mathrm{Cu}, \mathrm{Ti}, \mathrm{Co}, \mathrm{Ca}, \mathrm{Mn}$ and $\mathrm{Al}$ were placed in another cluster in the PCA. The different Components of the PCA might be showing different dynamics of metal. While PC1 might be representative of the bulk concentration of metals occurring in the sediments, PC2 can be representing the contribution from anthropogenic activities (pollution).

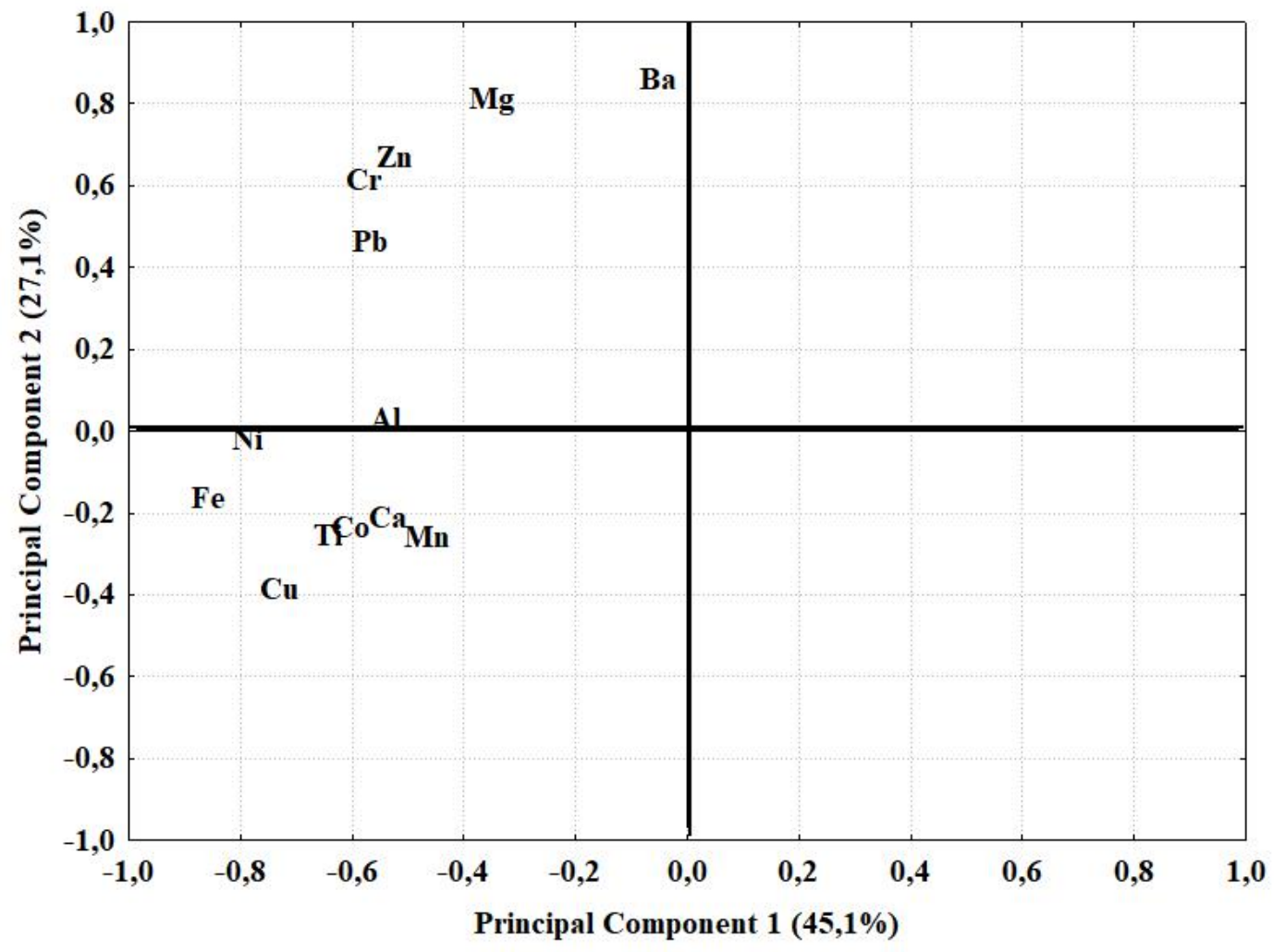

Figure 2

Results of the Principal Component Analysis (PCA) placing the elements with each respective loadings.

Table 5 - Results of the loadings of the elements and the percentage of the explained variability of the data from the PCA. Values in bold are the selected loadings that are the most important in explaining the variability of the component.

\begin{tabular}{lrr}
\hline Elements & \multicolumn{1}{c}{ PC 1} & \multicolumn{1}{c}{ PC 2} \\
\hline $\mathrm{Mg}$ & $-0,349052$ & $\mathbf{0 , 7 6 6 6 4 4}$ \\
$\mathrm{Al}$ & $-0,539857$ & $-0,016400$ \\
$\mathrm{Ca}$ & $-0,533589$ & $-0,257922$ \\
$\mathrm{Cr}$ & $-0,577863$ & 0,569693 \\
$\mathrm{Fe}$ & $\mathbf{- 0 , 8 5 5 9 1 8}$ & $-0,208539$ \\
$\mathrm{Co}$ & $-0,602699$ & $-0,282094$ \\
$\mathrm{Cu}$ & $\mathbf{- 0 , 7 2 9 4 9 2}$ & $-0,433832$ \\
$\mathrm{Ti}$ & $-0,642035$ & $-0,301015$ \\
$\mathrm{Mn}$ & $-0,465353$ & $-0,306932$ \\
$\mathrm{Ni}$ & $\mathbf{- 0 , 7 8 6 9 3 9}$ & $-0,068387$ \\
$\mathrm{Zn}$ & $-0,524285$ & 0,623913 \\
$\mathrm{Ba}$ & $-0,050607$ & $\mathbf{0 , 8 1 3 8 7 4}$ \\
$\mathrm{Pb}$ & $-0,565754$ & 0,417629 \\
\cline { 2 - 3 }$\%$ Expained. Variability & $45.1 \%$ & $27.1 \%$ \\
\hline
\end{tabular}


The plot of the sampled sites did not show a clear result (Fig. 3). Although it separated the sites located far apart from the spring (11 till 14), the other sites did not show a clear separation in relation to the transect across the river length. However, the pristine site (1) was placed far apart from all the other sites. This result is an indication that the pristine site has a statistical difference in metal concentration in relation to the other sites with anthropogenic pressures. The results of the PCA reinforces the results showed by EF and Igeo that there is a clear enrichment of metals in different compartments of the São Francisco river basin, and it is strongly related to the impact of the effluents of human activities.

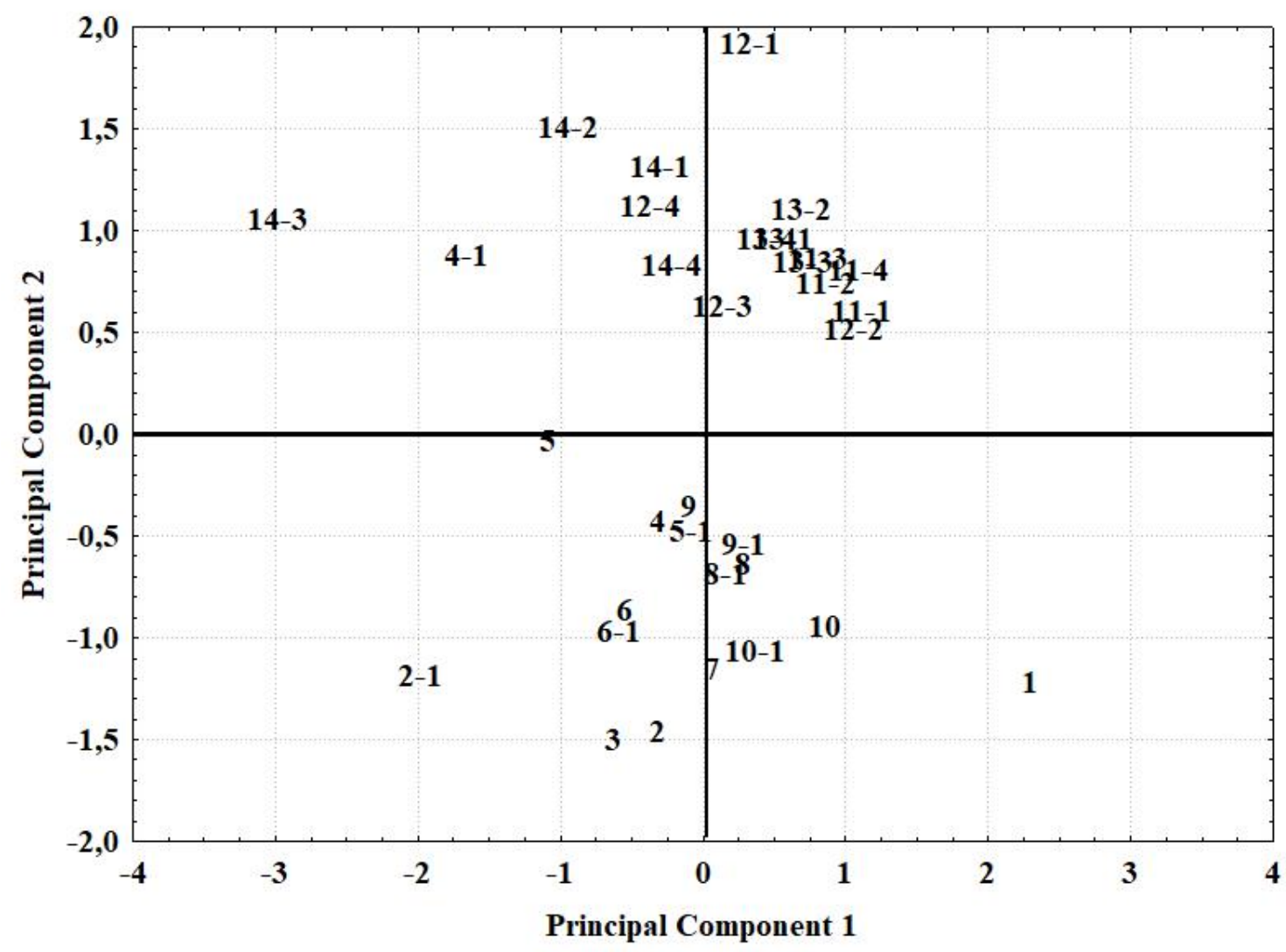

Figure 3

Score plot of the sampling sites position in relation to the results of the PCA. The numbers are across a transect from a pristine site close to the spring till the marginal lagoons further apart in Pirapora city.

When the different compartments sampled were plotted in relation to the PCA an interesting result was found (Fig. 4). The sediment of the lagoons were placed together and in the position of the cluster selected by PCA 2. And the other compartments were placed in relation to PCA 1. Other point was that the pristine site (D) was placed again far apart from the other sites showing that it can be used as a background site. And the other compartments although did not show a clear separation among them were placed close to each other. The results show that each compartment had its own dynamics in relation to the accumulation of metals present in the river basin. It also shows that the distance from the springs is not the major factor influencing the metal concentration, instead the type of habitat is more important in determining the accumulation of metals, as it was shown by EF and PCA.

Its clear that the marginal laggons were placed with the metals in PCA 2 which we discussed that could be indicating metals resulting from anthropogenic activities. This results shows that these types of habitats are important compartments retaining metals (Trindade 2016). 


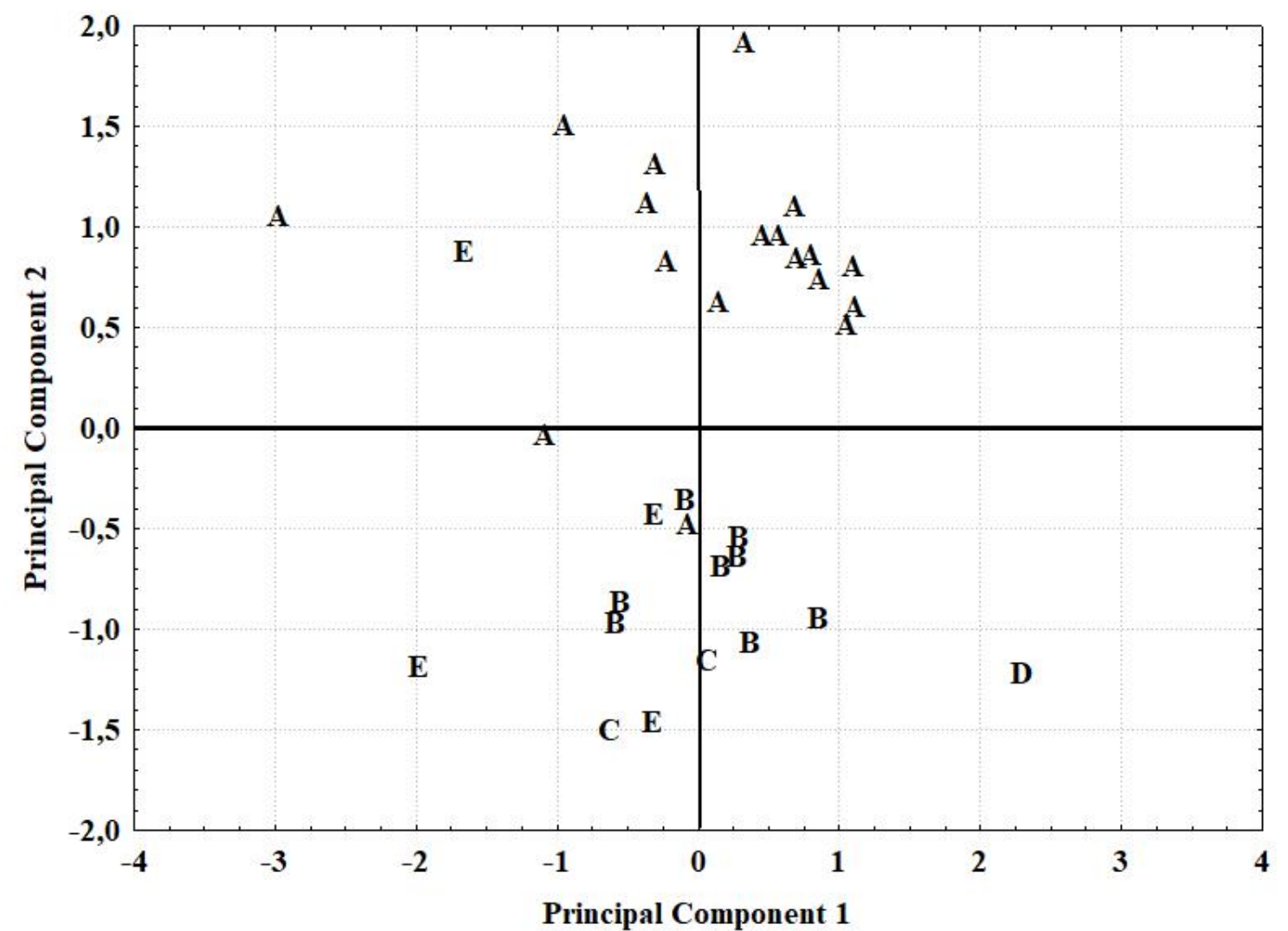

Figure 4

Score plot of the different compartments in relation to the results of the PCA. Where A: Sediments from marginal lagoons, B: Soils from inundation area or dry lagoons, C: Sediment from wet inundation areas, D: Sediment from pristine area of the river and E: Sediment from impacted areas of the river.

It is not clear which mechanism that can explain why the different compartments have different metal dynamics. We should expect that the distance from the pristine areas will correlate with metal concentration, which was not the case for all data analyses conducted. Our data showed that there is a difference in the type of metals that accumulates in each type of habitat. Moreover, habitats like inundation area show higher metal accumulation than the other types of habitats sampled. And

\section{CONCLUSIONS}

The results of this study have shown that metal dynamics are different in each type of habitat present in river system. The article presents the hypothesis that the differences in the accumulation of metals may be associated mainly with the fluvial dynamics of each sedimentary environment, especially considering the influence of the each type of habitat has its own dynamics as they were all separated in the PCA. To our knowledge this is the first study to address sediment metal contamination in different types of habitats of river systems. We could not find in the scientific literature any other study that addressed metal contamination in sediments of different habitats in a river hydrographic basin. More studies must be conducted to find if there is a pattern on metal accumulation in different compartments of a river system.

waters and the consequent mobilization of the sediment deposited by the increase of the competence and capacity of the river system in the wet periods. These dynamics must be taken into account to stablish environmental management practices for both protection and recovery of rivers polluted by metals. 


\section{ACKNOWLEDGEMENTS}

The authors thank CAPES for financial support for Dr. Torres Post Doctorate research (PNPD).

\section{REFERENCES}

ABNT 1984 Associação Brasileira de Normas Técnicas. NBR 7181: Solo - análise granulométrica (método de ensaio). Rio de Janeiro, $13 \mathrm{p}$.

Carman C.M., Li X.D., Zhang G., Wai O.W.H., Li, Y.S., 2007. Trace metal distribution in sediments of the Pearl River Estuary and the surrounding coastal area, South China. Environ. Pollut. 147: 311-323.

Ciazela J., Siepak M., Wojtowicz P. 2018. Tracking heavy metal contamination in a complex river-oxbow lake system: Middle Odra Valley, Germany/Poland. Sci. Total Environ. 616-617: 996-1006

Dai L., Wanga L., Li L., Liang T., Zhanga Y., Ma C., Xing B. 2017. Multivariate geostatistical analysis and source identification of heavy metals in the sediment of Poyang Lake in China. Sci. Total Environ. https://doi.org/10.1016/j.scitotenv.2017.10.0 85

Diaz-Alba D., Galindo-Riano M.D., CasanuevaMarenco M.J., García-Vargas M., Kosore C.M. 2011. Assessment of the metal pollution, potential toxicity and speciation of sediment from Algeciras Bay (South of Spain) using chemometric tools. J. Hazard. Mater. 190: 177-187.

Dotto C.B.S. \& Paiva E.M.C.D. 2006. Acumulação e balanço de sedimentos em superfícies asfálticas em área urbana de Santa Maria - RS. [Master's Dissertation] Programa de Pós- Graduação em Engenharia Civil, Universidade Federal de Santa Maria, Santa Maria - RS.

Ghrefat H.A., Yusuf N., Jamarh A., Nazzal J. 2012. Fractionation and risk assessment of heavy metals in soil samples collected along Zerqa River, Jordan. Environ. Earth Sci. 66 (1): 199-208.

Harguinteguy C.A., Cirelli A.F., Pignata M.L., 2014. Heavy metal accumulation in leaves of aquatic plant Stuckenia filiformis and its relationship with sediment and water in the Suquía River (Argentina). Microchem. J. 114: 111-118.

Heltai G., Percsich K., Halasz G., Jung K., Fekete I. 2005. Estimation of ecotoxicological potential of contaminated sediments based on a sequential extraction procedure with supercritical $\mathrm{CO}_{2}$ and

subcritical $\mathrm{H}_{2} \mathrm{O}$ solvents. Microchem. J. 79: 231-237.

Hill N.A., Simpson S.L., Johnston E.L. 2013. Beyond the bed: effects of metal conta mination on recruitment to bedded sediments and overlying substrata. Environ. Pollut. 173: 182-191.

Horn A.H., Baggio H. 2011. Desertification processes in the eastern central highlands of Brazil: caatinga-cerrado near the São Francisco Valle, Minas Gerais, and the ralationship with the deteorioration of life quality. Geowissenschaften (Boppard), 2: 105109;

Horn A.H., Baggio H., Schimith R.S. 2014. Selected element distribution in bottom sediment samples from Três Marias Lake and its significance, Minas Gerais, Brazil Roman. J. Miner. Dep. 87: 39-42

Horn A.H., Bilal E., Ribeiro V.E., Trindade W.M, Baggio H. 2012. The Impact on the water, soil and plants. The pollution generated by foundries in Pirapora and Varzéa da Palma. Carpath J. Earth Environm. 7: 211-218.

Islam M.S., Ahmedc Md.K., Raknuzzaman M., Al- Mamunb M.H., Islam M.K., 2015. Heavy metal pollution in surface water and sediment: A preliminary assessment of an urban River in a developing country. Ecolog. Indic. 48: 282-291.

Jiao, W., Ouyang, W., Hao, F., Lin, C. 2015. Anthropogenic impact on diffuse trace metal accumulation in river sediments from agricultural reclamation areas with geochemical and isotopic approaches Sci. Tot. Environ. 536 (2015) 609-615

Jollife I.T.1986. Principal Componente Analysis. New York: Brillinger, etc, 1986. (Springer Series in Statistics).

Loska K. \& Wiechuła D. 2003. Application of principal component analysis for the estimation of source of heavy metal contamination in surface sediments from the Rybnik Reservoir. Chemosphere 51: 723733.

Nemati K., Abu Bakar N.K., Abas M.R., Sobhanzadeh E. 2011. Speciation of heavy metals by modified BCR sequential extraction procedure in different depths of 
sediments from Sungai Buloh, Selangor, Malaysia. J. Hazard. Mater. 192: 402-410.

Palmares P., Horn A.H., Billal E., Iatan L.E. 2016. Heavy metals in vereda's soil of the Formosa River Basin, Buritizeiros, Minas Gerais, Brazil. Roman. J. Min. Dep. 89: 79-85

Passos E.A., Alves J.C., Santos I.S., Alves J.P., Garcia C.A.B., Costa A.C.S. 2010. Assessment of trace metals contamination in estuarine sediments using a sequential extraction technique and principal component analysis. Microchem. J. 96: 5057.

Patrus, M.L.R.A., Figueiredo, V.LS., Matos, A.R., Santos,, A.C.S., Menezes, I C.R., 2001. Parcela Mineira da Bacia do São Francisco: Caracterização hidroclimática e avaliação dos Recursos Hídricos de Superfície. In Pinto, C.P. \& Martins-Neto, M. (eds). Bacia do São Francisco: Geologia e recursos naturais. Belo Horizonte: SBGMG, Cap. 6, 93-138.

Pizarro P., Vergara P.M., Rodríguez J.A., Valenzuela A.M. 2010. Heavy metals in northern Chilean Rivers: Spatial variation and temporal trends. J. Hazar. Mat. 181: $747-754$

Pla L.E. 1986. Analisis Multivariado: Metodo de Componentes Principales. Washington: Chesneau, 1986. (Coleccion de Monografias Cientificas).

Reza R. \& Singh G. 2010. Heavy metal contamination and its indexing approach for River water. Internat. J. Environ. Sci. Techn. 7: 785-792.

Roberts D.A. 2012. Causes and ecological effects of resuspended contaminated sediments (RCS) in marine environments. Environ. Int. 40: 230-243.

Saleem M., Iqbal J., Shah M.H. 2015. Geochemical speciation, anthropogenic contamination, risk assessment and source identification of selected metals in freshwater sediments - A case study from Mangla Lake, Pakistan. Environ. Nanotech. Monit. Manag. 4: 27-36.

Salomons W. \& Forstner W. 1984. Metals in the hydrocycle. Berlin: Springer-Verlag.

Sundelin B. \& Eriksson A.-K. 2001. Mobility and bioavailability of trace metals in sulfidic coastal sediments. Environ. Toxicol. Chem. 20: 748-756.

Tamim U., Khan R., Jolly Y.N., Fatema K., Das S., Naher K., Islam M.A., Islam S.M.A., Hossain S.M. 2016. Elemental distribution of metals in urban river sediments near an industrial effluent source. Chemosphere 155 : $509-518$.
Trindade W. 2016. Composição Granulométrica E Concentrações De Metais Pesados De Sedimentos Em Lagoas Marginais Do Rio São Francisco - MG. PhD Thesis. Universidade Federal de Minas Gerais. Pós Graduação em Geografia.

Tuna A.L., Yilmaz F., Demirak A., Ozdemir N. 2007. Sources and distribution of trace metals in the Saricay Stream basin of southwestern Turkey. Environ. Monitor. Assess. 125: 47-57.

U.S - EPA 1998. United States Environmental Protection Agency SW 846 (method 3051): microwave assisted acid digestion of sediments, sludges, soils and oils. Available in : http://www.caslab.com/EPA-Method$3051 /$.

Valentin J.L. 1995. Agrupamento e Ordenação. In: Oecologia Brasiliensis, Rio de Janeiro: Perez-Neto etc, 1995. v. 2. P. 27-55 a

Weber P., Behr E.R., Knorr C.L., Vendruscolo D.S., Flores R.M.M., Dressler V.L., Baldisserotto B. 2013. Metals in the water, sediment, and tissues of two fish species from different trophic levels in a subtropical Brazilian River. Microch. J. 106: 61-66

Yousafzai A.M., Chivers D.P., Khan A.R., Ahmad I., Siraj M. 2010. Comparison of heavy metals burden in two freshwater fishes Wallago attu and Labeo dyocheilus with regard to their feeding habits in natural ecosystem. Pak. J. Zool. 42 (5), 537-544. 